\title{
Using Candida oleophila as a biocontriol agens to prevent foodborne Escherichia coli 0157 EHEC infections
}

\author{
Yujian Wang ${ }^{1 *}$, An Wei ${ }^{2}$ and Hongyu $\mathrm{Li}^{3}$
}

\begin{abstract}
Escherichia coli O157:H7 (EHEC O157) is a serious pathogen causing haemorrhagic colitis. In this study, inactivation kinetics of inoculated EHEC 0157 and response of EHEC O157 in apple wounds by different concentrations of C. oleophila was investigated. The results presented in this study indicated that EHEC 0157 could survive and grow in wounded 'Fuji' apples and extensively proliferate. Water as a decontaminant was ineffective in reducing EHEC 0157 in wounded apples. C. oleophila could be a viable method of controlling wound contaminated by this pathogen at room temperature.
\end{abstract}

Keywords: Escherichia coli O157:H7, Candida oleophila, Apple wounds, Response

\section{Introduction}

Foodborne bacterial infections can affect high numbers of people with large-scale outbreaks occurring. There have been a number of outbreaks due to Escherichia coli O157: H7 (EHEC O157). EHEC O157 was first recognized as a human pathogen in 1982 during the investigation of two outbreaks of bloody diarrhoea in Oregon and Michigan (USA) (Riley et al. 1983). Outbreaks of the infections have now been reported from United States and Canada (Bell et al. 1994), Asia (Michino et al. 1998), Australia (Desmarchelier 1996) and Europe (Williams et al. 2000).

One of the biggest problems with controlling EHEC O157 outbreaks is the low infectious dose required for infection to occur (Strachan et al. 2001; Teunis et al. 2004). This means that even slight contamination of surfaces or work areas may cause serious infection. Many vegetable and fruit products such as apple, raspberries and strawberries can be contaminated. Injuries to apples through stem punctures, bird pecks or wounds created when they drop and by other various types of physical abuse may permit entry of pathogens such as EHEC O157 from animal feces, contaminated water, dust or

\footnotetext{
* Correspondence: wangyujian@cib.ac.cn

'Key Laboratory of Environmental and Applied Microbiology, Chengdu Institute of Biology, Chinese Academy of Sciences, Chengdu 610041, People's Republic of China

Full list of author information is available at the end of the article
}

soil (Riordan et al. 2000). Dingman (2000) reported the ability of E. coli O157:H7 to survive and grow in the areas of injury on an apple, and thus, there exists a food safety risk associated with those apples to be consumed raw or destined for the production of unpasteurized apple cider. Recent outbreaks of foodborne illness associated with consumption of fruit juices, in particular apple cider, has led to published regulations by the U.S. Food and Drug Administration (FDA) proposing mandatory adoption of hazard analysis critical control point (HACCP) programs (FDA Food and Drug Administration 1998; Annous et al. 2001). In this way, EHEC O157 presents a serious public health risk from cross-contamination from surfaces to food produce.

Yeasts have been studied for more than two decades as biological control agents against postharvest diseases caused by fungal pathogens of fruit. Wounded fruit, in particular, needs protection because wounds are primary sites of infection by several postharvest fungal pathogens. Cryptococcus laurentii, Pichia guilliermondi, Kloeckera apiculata, Sporobolomyces roseus, Candida sake and Candida oleophila (Usall et al. 2000, 2001; Abadias et al. 2001; Gamagae and Sivakumar 2004; Lassois et al. 2008) have shown biocontrol effectiveness against postharvest diseases caused by fungal pathogens of apple. Recently, inhibition of E. coli and other enterobacteria by Pichia anomala and Hansenula anomala yeast in storage systems 
has been shown by M. Olstorpe and colleagues (Olstorpe et al., 2010, 2012). There is few scientific literature about application of $C$. oleophila yeast as antagonist for controlling of EHEC O157 in vegetable or fruit products.

In this study, inactivation kinetics of inoculated EHEC O157 in apple wounds using C. oleophila was studied. The main objective of this research is to investigate the feasibility and effectiveness of C. oleophila for reducing population of EHEC O157.

\section{Materials and methods Apples}

Unwaxed 'Fuji' apples were purchased from a local grocery store. Apples were of uniform size $(230 \pm 10 \mathrm{~g})$ and were free of visible defects such as bruises, cuts, or abrasions. The apples were stored at $2^{\circ} \mathrm{C}$ and used in experiments within 7 days. Before use, the apples were washed with $2 \%$ sodium hypochlorite for $2 \mathrm{~min}$, rinsed with deionized water, and air-dried before wounding.

\section{Microorganisms}

Clinically isolated EHEC O157 was kindly provided by Third Military Medical University (Chongqing, China). Cultures propagated at $30^{\circ} \mathrm{C}$ for $20 \mathrm{~h}$ in $10 \mathrm{ml}$ of tryptic soy broth (TSB), were harvested and washed three times by centrifugation at $2000 \times \mathrm{g}$ for $10 \mathrm{~min}$ at $4^{\circ} \mathrm{C}$ in $0.9 \%$ $(\mathrm{w} / \mathrm{v})$ sodium chloride solution to yield an approximate population of $1 \times 10^{7} \mathrm{CFU} / \mathrm{ml}$.

Yeast C. oleophila strain was isolated by Bioengineering College of Lanzhou jiaotong University, Lanzhou, and stored at $-80^{\circ} \mathrm{C}$ in glycerol solution (50\%). The cultures were maintained on nutrient-yeast extract-dextrose Agar (NYDA) slants ( $8 \mathrm{~g}$ of nutrient broth, $5 \mathrm{~g}$ of yeast extract, $10 \mathrm{~g}$ of dextrose, $20 \mathrm{~g}$ of agar and $1000 \mathrm{ml}$ of water) at $4^{\circ} \mathrm{C}$. Nutrient broth was purchased from Qingdao Hope Biotechnology Co., Ltd. China. C. oleophila was grown at $24^{\circ} \mathrm{C}$ for $48 \mathrm{~h}$ in $500 \mathrm{ml}$ shake flask cultures in nutrient yeast broth (NYDB). Then the cells were harvested at $5000 \times \mathrm{g}$ for $10 \mathrm{~min}$ at $4^{\circ} \mathrm{C}$ and resuspended in deionized water $\left(1 \times 10^{8} \mathrm{CFU} / \mathrm{ml}\right)$. Desired concentrations were adjusted with the aid of a hemacytometer.

\section{Apple streatments}

Fruits were wounded at five sites about midway between the stem and the equator with a metal bar which was pressed against the skin until it ruptured, making triangular wounds of about $4 \mathrm{~mm}$ each side. Each wound was inoculated with $20 \mu \mathrm{l}$. oleophila suspension and $20 \mu \mathrm{l}$ EHEC O157 suspension $\left(10^{7} \mathrm{CFU} / \mathrm{ml}\right)$. The concentrations of inoculated $C$. oleophila were $10^{8} \mathrm{CFU} / \mathrm{ml}$ (K8), $10^{7} \mathrm{CFU} / \mathrm{ml}$ (K7), $10^{6} \mathrm{CFU} / \mathrm{ml}$ (K6), $10^{5} \mathrm{CFU} / \mathrm{ml}$ (K5), $0 \mathrm{CFU} / \mathrm{ml}$ (K0), just inoculated with EHEC O157) respectively. Then the apples were placed in perforated plastic trays and stored at $25^{\circ} \mathrm{C}$. Following treatment, the apples were rinsed by dipping in sterile water at $25^{\circ} \mathrm{C}$ for $30 \mathrm{~s}$ and left to dry.

\section{Sampling and microbial analysis}

The concentrations of yeast and EHEC O157 population were monitored every day. On each sampling day, three apples were removed from each tray and the wounds were taken from each fruit using a sterile cork borer of $13 \mathrm{~mm}$ in diameter. Then the wounds were placed in a sterile plastic bag with $90 \mathrm{ml}$ of $0.1 \%$ peptone $(\mathrm{w} / \mathrm{v})$ solution and blended. The resulting suspension was serially diluted in $0.1 \%$ peptone and $100 \mu \mathrm{l}$ was applied to Petri plates in triplicate. Candida oleophila was isolated on malt extract agar supplemented with streptomycin sulphate $\left(100 \mu \mathrm{g} \mathrm{ml}^{-1}\right)$. Yeast colonies were counted after three days at $24^{\circ} \mathrm{C}$. EHEC O157 was isolated on tryptic soy agar (TSB) incubated at $37^{\circ} \mathrm{C}$ for one day to determine colonies. An analysis of variance of the $\log _{10}$ transformed data was carried out for each sampling day.

\section{Statistical analysis}

All experiments were replicated three times. The data presented are the means of triplicate experiments. Significant difference was determined at $5 \%$ level of significance $(\mathrm{P}<0.05)$ by Student's $t$-test.

\section{Results}

Concentration dynamics of EHEC O157 in apple wounds without inoculating with $C$. oleophila was investigated. The initial population of total EHEC O157 was about $5.5 \log$ CFU in an apple wound. Population dynamics of EHEC O157 in wounded apple during storage period in this study are shown in Figure 1. The EHEC O157 population decreased during the first $24 \mathrm{~h}$ at $25^{\circ} \mathrm{C}$. Subsequently, it increased progressively to reach maximum population

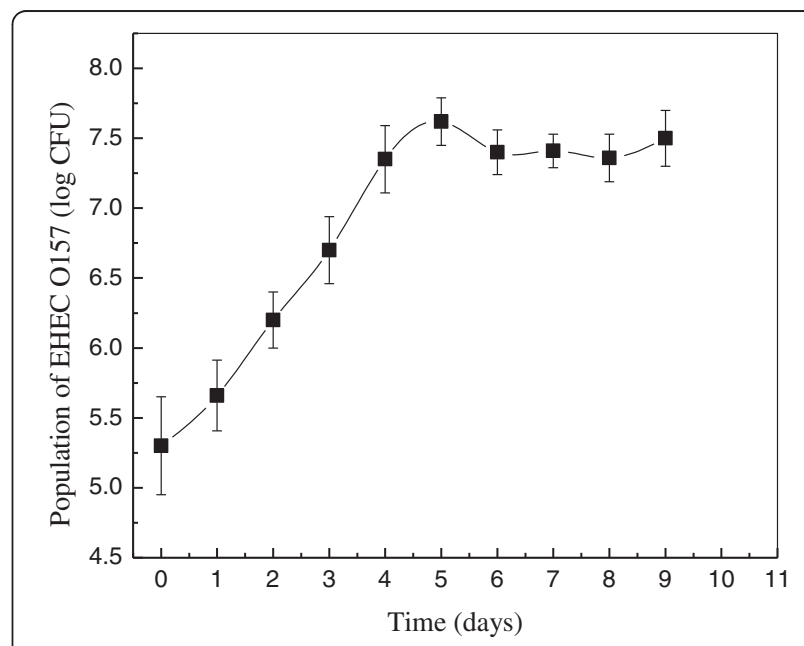

Figure 1 Concentration dynamics of EHEC 0157 during storage at $25^{\circ} \mathrm{C}$ without $\mathrm{C}$. oleophila. 
of $7.6 \log$ CFU/wound after about $5 \mathrm{~d}$ of storage. After that the population remained stable. Water treatment was carried out at day 6. However, it caused little change in pathogens count with a reduction of about $0.4 \log \mathrm{CFU} /$ wound of EHEC O157

Concentration dynamics of EHEC O157 in wounded apples during storage at $25^{\circ} \mathrm{C}$ after treatments by different concentration of C. oleophila is shown in Figure 2. Inoculum of $C$. oleophila showed a significant effect on development of EHEC O157. The higher concentration of $C$.oleophila inoculated, the smaller increase of EHEC O157 was. Compared with K8 (C. oleophila, $\left.10^{8} \mathrm{CFU} / \mathrm{ml}\right)$, $\mathrm{K} 5$ (C. oleophila, $\left.10^{5} \mathrm{CFU} / \mathrm{ml}\right)$, as applied in this study, did not result in effective reduction of EHEC O157 populations in the first $12 \mathrm{~h}$, but was able to significantly $(\mathrm{P}<0.05)$ impede growth of the pathogen at the following time. The maximum populations of EHEC O157 inoculated with $\mathrm{K} 5, \mathrm{~K} 6, \mathrm{~K} 7$ and $\mathrm{K} 8$ were $6.8,6.5,6.1,6.0 \mathrm{CFU} /$ wound after 4 days of storage at $25^{\circ} \mathrm{C}$, respectively. So $\mathrm{K} 7$ (C. oleophila, $10^{7} \mathrm{CFU} / \mathrm{ml}$ ) could be most appropriate for prevention growth of EHEC O157 at room temperature.

The C. oleophila populations inoculated with EHEC O157 increased evidently to maximum populations during the first 2 days following its application to wounded apples with little changes thereafter. The result was presented in Figure 3. Mean maximum populations of $C$. oleophila recovered from apples did not differ significantly each other regardless of initial inoculum concentrations.

\section{Discussion}

Water treatment didn't cause a significant change in pathogens count with a reduction of about $0.4 \log$ CFU/ wound of EHEC O157. This was less than that reported by similar research evaluating the rinsing effect on apple

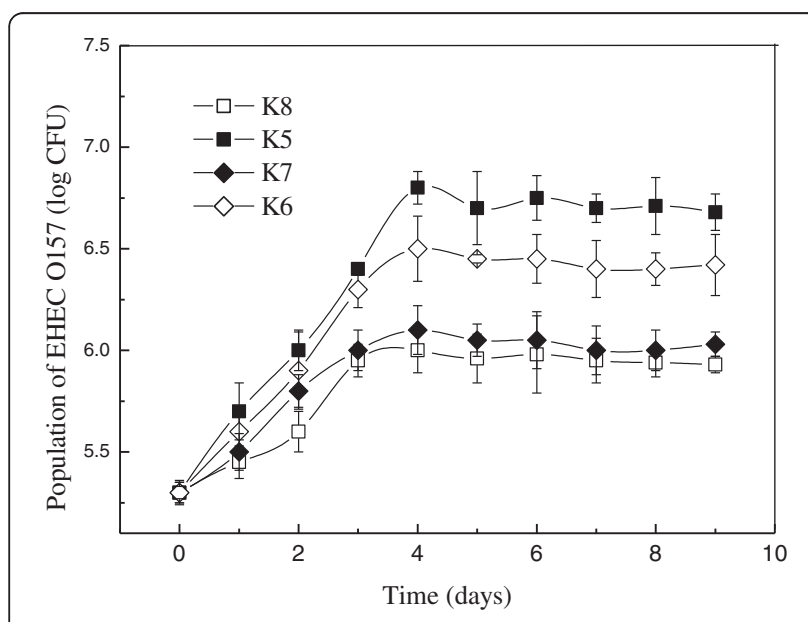

Figure 2 Concentration dynamics of EHEC 0157 during storage at $25^{\circ} \mathrm{C}$ with C. oleophila.

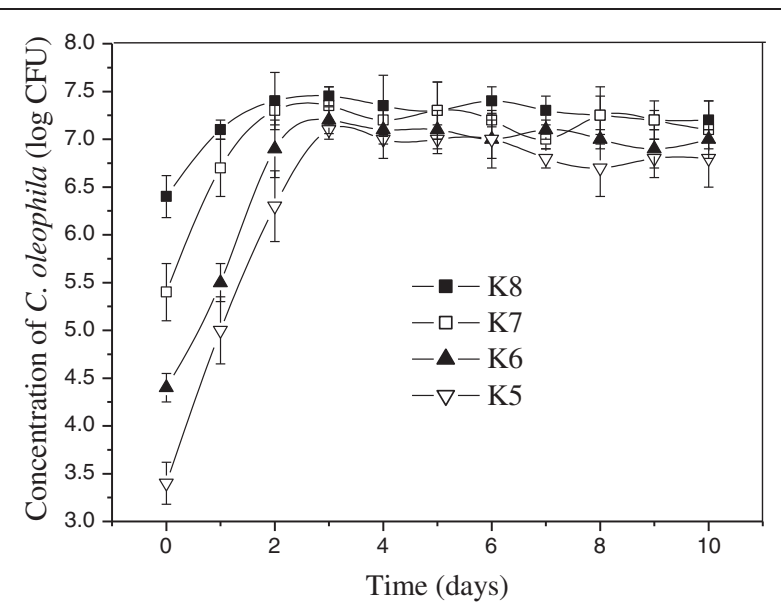

Figure 3 Concentration dynamics of $C$. oleophila during storage at $25^{\circ} \mathrm{C}$ with $\mathrm{EHEC} 0157$.

surfaces previously (Ruiz-Cruz et al. 2007; Wright et al. 2000a, 2000b). Attachment would be stronger in wounds due to the fibrous structure and porous nature of the apple tissue as compared with the smooth. These studies demonstrated that EHEC O157 could grow at room temperature and the use of water is insufficient to eliminate the pathogen in wounded 'Fuji' apples. Therefore the use of effective antagonist is necessary to prevent growth of EHEC O157.

The stoppage in growth of biocontrol agents in fresh wounds after the rapid initial increase is likely to be due to the population exhausting certain factors and reaching the carrying capacity of the wound. The result showed that the C. oleophila could grow well in wounded apples. A 4-log increase of C. oleophila (K5) was attained after 3 days of storage at $25^{\circ} \mathrm{C}$. Similarly, previous studies showed that antagonist populations could grow exponentially in Red Delicious and stabilize after their application to wounds regardless of the population level or the addition of supplemental nutrients (Mercier and Wilson 1995). Furthermore, no other organisms were isolated in significant numbers during the course of this experiment. Athough apple wounds are probably colonized by other natural bacteria (Mercier and Wilson 1994), it is unlikely that they could be important enough to interfere with growth of C. oleophila.

From discussion above it can be concluded that EHEC O157 could survive and grow in wounded 'Fuji' apples and can extensively proliferate at room temperature. The use of water as a decontaminant was ineffective in reducing EHEC O157 in wounded apples. C. oleophila effectively reduced the development of EHEC O157, at the same time the concentrations of $C$. oleophila also affect the growth of the pathogen significantly. However, there were no significant differences in C. oleophila populations 
recovered from wounded apples. Further studies need to be conducted to address the issue of effect factor and interaction mechanism between the yeast and bacteria.

\section{Competing interest}

The authors declare that they have no competing interest with this work.

\section{Authors' contributions}

YJW, AW, HYL carried out the experiments and field studies, YJW drafted and revised the manuscript. All authors read and approved the final manuscript.

\section{Acknowledgements}

The authors would like to express their gratitude to School of Life Science, Lanzhou University, Chemical and biological engineer School, Lanzhou Jiaotong University, Department of Clinical Microbiology, Third Military Medical University and Pangang Group company for support and assistance. The authors are grateful to Western Light Talent Culture Project (Y2C5031).

\section{Author details}

'Key Laboratory of Environmental and Applied Microbiology, Chengdu Institute of Biology, Chinese Academy of Sciences, Chengdu 610041, People's Republic of China. 'Department of chemical engineering, Boston University, Boston, MA 02215, USA. ${ }^{3}$ Institute of Microbiology, School of Life Sciences, Lanzhou University, Lanzhou 730000, People's Republic of China.

Received: 9 October 2012 Accepted: 17 December 2012 Published: 28 December 2012

\section{References}

Abadias M, Benabarre A, Teixidó N, Usall J, Viñas I (2001) Effect of freeze drying and protectants on viability of the biocontrol yeast Candida sake. Int J Food Microbiol 65:173-182

Annous BA, Sapers GM, Mattrazzo AM, Riordan DCR (2001) Efficacy of washing with a commercial flatbed brush washer, using conventional and experimental washing agents, in reducing populations of Escherichia coli on artificially inoculated apples. J Food Protect 64:159-163

Bell BP, Goldoft M, Griffin PM, Davis MA, Gordon DC, Tarr PI (1994) A multistate outbreak of Escherichia coli 0157:H7-associated bloody diarrhoea and hemolytic uremic syndrome from hamburgers: the Washington experience. Jama-J Am Med Assoc 272:1349-1353

Desmarchelier PM (1996) Foodborne disease: emerging problems and solutions. Med J Australia 165:668-671

Dingman DW (2000) Growth of Escherichia coli 0157:H7 in bruised apple (Malus domestica) tissue as influenced by cultivar, date of harvest, and source. Appl Environ Microb 66:1077-1083

FDA (Food and Drug Administration), (1998) Hazard analysis and critical control point (HACCP); procedures for the safe and sanitary processing and importing of juice. Fed Regist 63:20450-20486

Gamagae SU, Sivakumar D (2004) Evaluation of post-harvest application of sodium bicarbonatein corporated wax formulation and Candida oleophila for the control of anthracnose of papaya. Crop Prot 23:575-579

Lassois L, de Lapeyre de Bellaire L, Jijakli H (2008) Biological control of crown rot of bananas with Pichia anomala strain $\mathrm{K}$ and Candida oleophila strain $\mathrm{O}$. Biol Control 45:410-418

Mercier J, Wilson CL (1994) Colonization of apple wounds by naturally occurring microflora and introduced Candida oleophila and their effect on infection by Botrytis cinerea during storage. Biol Control 4:138-144

Mercier J, Wilson CL (1995) Effect of wound moisture on the biocontrol by Candida oleophila of gray mold rot (Botrytis cinerea) of apple. Postharvest Bio tech 6:9-15

Michino H, Araki K, Minami K, Nakayama S, Ejima T, Hiroe Y (1998) Recent outbreaks of infections caused by Escherichia coli 0157:H7 in Japan. In: Kaper JB, O'Brien AD (eds) Escherichia coli O157:H7and other Shiga toxin-producing E. coli strains. American Society for Microbiology, Washington, DC, pp 73-81

Olstorpe M, Borling J, Schnürer J, Passoth V (2010) Pichia anomala yeast improves feed hygiene during storage of moist crimped barley grain under Swedish farm conditions. Anim Feed Sci Tech 28:47-56

Olstorpe M, Schnürer J, Passoth V (2012) Growth Inhibition of Various Enterobacteriaceae Species by the Yeast Hansenula anomala during Storage of Moist Cereal Grain. Appl Environ Microbiol 78:292-294
Riley LW, Remis RS, Helgerson SD, McGee HB, Wells JG, Davis BR (1983) Hemorrhagic colitis associated with a rare Escherichia coli serotype. N Engl J Med 308:681-685

Ruiz-Cruz S, Acedo-Félix E, Díaz-Cinco M, Islas-Osuna MA, González-Aguilar GA (2007) Efficacy of sanitizers in reducing Escherichia coli O157:H7, Salmonella spp. and Listeria monocytogenes populations on fresh-cut carrots. Food Control 18:1383-1390

Riordan DCR, Sapers GM, Annous BA (2000) The survival of Escherichia coli O157: $\mathrm{H} 7$ in the presence of Penicillium expansum and Glomerella cingulata in wounds on apple surfaces. J Food Prot 63:1637-1642

Strachan NJC, Fenlon DR, Ogden ID (2001) Modelling the vector pathway and infection of humans in an environmental outbreak of Escherichia coli 0157. FEMS Microbiol Lett 203:69-73

Teunis P, Takumi K, Shinagawa K (2004) Dose response for infection by Escherichia coli O157:H7 from outbreak data. RiskAnal 24:401-407

Usall J, Teixidó N, Torres R, Ochoa de Eribe X, Viñas I (2001) Pilot tests of Candida sake (CPA-1) applications to control postharvest blue mold on apple fruit. Postharvest Biol Tech 21:147-156

Usall J, Teixidó N, Fons E, Viñas I (2000) Biological control of blue mould on apple by a strain of Candida sake under several controlled atmosphere conditions. In J Food Microb 58:83-92

Wright JR, Sumner SS, Hackney CR, Pierson MD, Zoecklein BW (2000a) Reduction of Escherichia coli O157:H7 on apples using wash and chemical sanitizer treatments. Dairy Food Environ Sanitation 20:120-126

Wright JR, Sumner SS, Hackney CR, Pierson MD, Zoecklein BW (2000b) Efficacy of ultraviolet light for reducing Escherichia coli 0157:H7 in unpasteurized apple cider. J Food Protect 63:563-567

Williams RC, Issacs S, Decou ML, Richardson EA, Buffett MC, Slinger RW (2000) Illness outbreak associated with E. coli 0157:H7 in Genoa salami. Can Med Assoc J 162:1409-1413

doi:10.1186/2193-1801-1-82

Cite this article as: Wang et al:: Using Candida oleophila as a biocontriol agens to prevent foodborne Escherichia coli O157 EHEC infections. SpringerPlus 2012 1:82.

\section{Submit your manuscript to a SpringerOpen ${ }^{\circ}$ journal and benefit from:}

- Convenient online submission

- Rigorous peer review

- Immediate publication on acceptance

- Open access: articles freely available online

- High visibility within the field

- Retaining the copyright to your article

Submit your next manuscript at $\boldsymbol{\wedge}$ springeropen.com 